\title{
Fire-associated reptile mortality in Tembe Elephant Park, South Africa
}

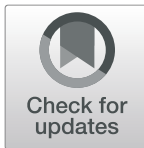

Philip R. Jordaan ${ }^{1}$, Johan C. A. Steyl ${ }^{2}$, Catharine C. Hanekom ${ }^{3}$ and Xander Combrink ${ }^{1 *}$ (D)

\begin{abstract}
Background: Even though fire has been used extensively as part of conservation management in South Africa, its impact on the life history and mortality of fossorial reptiles is poorly documented. We conducted post-fire transects after three controlled burns during different seasons in Tembe Elephant Park, recorded 14 reptile species, and found fewer mortalities in winter compared to spring.

Results: Histopathological examinations of species were conducted from different microhabitats to elucidate the possible cause of death. The unburned condition of most mortality specimens prompted suspicion of particulate smoke inhalation as a possible cause of death. However, the relative absence of carbon-rich particulate matter and the occasional presence of pulmonary oedema suggested asphyxiation, heat-induced cardiac arrest, or gas intoxication as the most likely cause of death. The association of most specimens with microhabitats rich in leaf litter may indicate higher reptile densities in this habitat or increased mortalities due to smoldering detrital material, or both. Detrital combustion and smoldering may result in advective transportation of heated gasses into underlying soil layers, with subsequent increased mortalities.
\end{abstract}

Conclusion: Even though burrowing could potentially offer protection from fire to fossorial vertebrates through vertical movements into deeper substrate, our results indicated that they are not necessarily protected from fire effects. We speculate that seasonal reproductive behavior may contribute to fire mortality. These observations may contribute to improved understanding and management of fire in areas where fossorial reptiles occur.

Keywords: direct fire effects, fire-associated mortality, histopathology, reptile, Tembe Elephant Park

\section{Resumen}

Antecedentes: Aunque el fuego ha sido extensivamente usado como parte del manejo conservativo en Sudáfrica, su impacto en la historia de vida y mortalidad de reptiles excavadores ha sido muy pobremente documentado. A través de transectas post-fuego ubicadas en tres quemas prescriptas hechas en diferentes estaciones en el Parque Nacional de Tempbe, registramos 14 especies de reptiles y encontramos menos mortalidad en quemas realizadas en invierno comparadas con quemas de primavera.

(Continued on next page)

\footnotetext{
*Correspondence: CombrinkAS@tut.ac.za

${ }^{1}$ Department of Nature Conservation, Tshwane University of Technology,

Private Bag X680, Pretoria, South Africa

Full list of author information is available at the end of the article
} 
(Continued from previous page)

Resultados: Exámenes histopatológicos de las especies fueron realizados de diferentes micro-hábitats para elucidar posibles causas de mortalidad. La condición de no-quemado en la mortalidad de especímenes incitó a sospechar que la inhalación de partículas de humo podría ser una posible causa de su muerte. Sin embargo, la ausencia relativa de partículas de carbono enriquecido y la presencia ocasional de edemas de pulmón sugieren que la asfixia, el paro cardíaco como consecuencia del calor, o la intoxicación por gases serían las causas de muerte más probables. La asociación de la mayoría de los especímenes con micro-hábitats ricos en mantillo de hojas podría indicar una mayor densidad de reptiles en este hábitat, un incremento en la mortalidad debido a la combustión latente (sin llamas) del material del mantillo, o a ambos. La combustión lenta y sin llamas del mantillo puede resultar en el transporte advectivo de gases calientes hacia horizontes más bajos del suelo, con el consecuente incremento en la mortalidad.

Conclusiones: Aunque las cuevas usadas como refugio pueden potencialmente ofrecer protección al fuego a los vertebrados excavadores a través de movimientos verticales a sustratos más bajos, nuestros resultados muestran que no necesariamente los protegen de los efectos del fuego. Especulamos que el comportamiento reproductivo estacional puede contribuir a la mortalidad por fuego. Estas observaciones pueden contribuir a mejorar el entendimiento y manejo del fuego en áreas donde viven los reptiles excavadores.

\section{Introduction}

Tropical savannas have the potential to harbor high levels of vertebrate diversity, which are considered well adapted to frequent fire events, despite occasional high fire casualty rates (Bigalke and Willan 1982). Few studies have been conducted on the effect of fire on southern African reptile fauna (Parr and Chown 2003; Masterson et al. 2008; Branch 2014), with published observations regarding direct fire impact on reptiles within the region generally being unquantified. The direct impact of vegetation combustion regarding faunal mortality or injury is considered of little consequence when compared to indirect longterm fire effects on faunal populations (Neary et al. 1999; Russell et al. 1999; Engstrom 2010), although observations documenting the direct effect of burning management on animal diversity may improve decision-making capabilities for conservation management (Smith et al. 2012).

This field note reports on the density of observed reptile mortalities following fires in savanna vegetation, while describing mechanisms potentially responsible for the death of collected individuals based on post mortem histopathological analyses. Such analyses contribute to the mechanistic understanding of fire-induced faunal mortality, which is globally lacking (Dickenson et al. 2010). The differences in mortality density between seasonal fires are discussed with regard to environmental conditions, species' life histories, and the physical attributes of collected samples.

\section{Methods}

Tembe Elephant Park is a provincial game reserve in northern KwaZulu-Natal Province, South Africa (-27.042778 $\left.32.423889^{\circ}\right)$. The area lies within the Mozambique coastal plain where the terrain is dominated by vegetated sandy deposits (Matthews et al. 2001). Sections of Tembe sandy bushveld (Mucina and Rutherford 2006) were burned by fires A, B, and C during 2015 by Tembe Elephant Park management to combat sickle bush (Dichrostachys cinerea [L.] Wight et Arn.) and silver cluster-leaf (Terminalia sericea Burch. ex DC.) encroachment. Three different sites were surveyed for fire-associated reptile mortality the morning following burning. Fires A and B were set during the austral winter, while Fire $\mathrm{C}$ was set during early spring. All three surveyed fires were head fires, ignited using a line ignition method along the internal reserve road network, and were previously burned during 2013. Surveys were conducted at elevations ranging between 70 to 81 meters above sea level along a negligible slope. Fire A was set at 1400 hours on 13 August 2015 at an ambient temperature of $31^{\circ} \mathrm{C}$ and a mean wind speed of $17.64 \mathrm{~km} \mathrm{hr}^{-1}$. The total block that burned where surveys took place was estimated at 300 ha. Fire B followed on 14 August 2015 and was ignited at 1200 hours. Surveys were situated in a 180 ha burn. Ambient temperature at the time of ignition was $26.8{ }^{\circ} \mathrm{C}$ with a wind speed of $4.68 \mathrm{~km} \mathrm{hr}^{-1}$. Fire $\mathrm{C}$ was set on 13 October 2015 at 1000 hours at an ambient temperature of $30.1{ }^{\circ} \mathrm{C}$ and a mean wind speed of $4.68 \mathrm{~km} \mathrm{hr}^{-1}$, which was recorded by an automated weather station. Temperatures as high as $43{ }^{\circ} \mathrm{C}$, however, were documented by management staff present at the fire. A total area of 2.6 ha was surveyed for both Fire A and B, along transects totaling $6500 \mathrm{~m}$. Fire $\mathrm{C}$ was surveyed by transects measuring a total of $2000 \mathrm{~m}$ in length, covering 0.8 ha.

Four-meter-wide transects were surveyed through each burn scar, with all encountered reptile mortalities collected, and the associated microhabitat for each specimen recorded. Reptile mortality density per hectare (mortality $\mathrm{ha}^{-1}$ ) was extrapolated for each fire based on survey data. As species-specific traits may predispose or protect fauna from fire (Panzer 2002), the habitat preferences of collected species were obtained from literature accounts (primarily Branch 1998 and Maritz and 
Alexander 2008) and tabulated along with mortality results (Table 1).

Before preserving specimens in 10\% buffered formalin, external examinations were conducted, describing visible thermal damage. Post mortem histopathological sample preparation largely consumed specimens. Preparation of samples for histopathological examination entailed the dissection of vital tissues of specimens into several cross sections less than $5 \mathrm{~mm}$ thick, followed by routine processing with haematoxylin and eosin staining for light microscopic examination (Bancroft and Gamble 2002). This was performed with the aim of determining possible mechanism(s) of mortality.

\section{Results}

Fourteen reptile taxa, consisting of six lizard and eight snake species, were recorded during the surveys. The density of reptile mortalities from Fire $\mathrm{C}$ was considerably higher (46.3 mortalities $\mathrm{ha}^{-1}$ ) than that for Fire A or B (2.3 and 4.2 mortalities ha ${ }^{-1}$, respectively).

Specimens from microhabitats associated with woody vegetation and leaf litter were more abundant compared to fire casualties associated with open grass patches (Table 2). Unexpectedly, fossorial reptiles were found dead on the surface of the soil, some in positions that suggested these animals attempted to vacate the substrate in favor of the surface. There was no visible external burn tissue damage to the reptile mortalities we evaluated from Fire A or B, and less than $30 \%$ of the mortalities from Fire $\mathrm{C}$ had external damage.

Three specimens-a Maputaland legless skink (Acontias parietalis, Broadley 1990), southern African python (Python natalensis, A. Smith 1840), and yellowthroated plated lizard (Gerrhosaurus flavigularis, Wiegmann 1828)—exhibited oral bleeding, as observed during external examination. Histopathological examination using light microscopy did not indicate any lesions on most of the vital organs and tissues of specimens from Fires A and B. Twenty-seven specimens from Fire C were prepared for analyses, four of which were unsuitable for meaningful histological examination, resulting in a total examined sample of 23 specimens. Various degrees of pulmonary oedema (Fig. 1) were identified in $61 \%(n=14)$ of the analyzed sample for the following species: Cape centipede eater (Aparallactus capensis, A. Smith 1849), Cape dwarf gecko (Lygodactylus capensis, A. Smith 1849), Wahlberg's snake-eyed skink (Panaspis wahlbergi, A. Smith 1849), Jan's shovel-snout (Prosymna janii, Bianconi 1862), Zululand dwarf burrowing skink

Table 1 Species specific habitat preference and mortality density in mortalities ha ${ }^{-1}$, and number in parentheses. Tembe Elephant Park, South Africa, 13 and 14 August and 14 October 2015

\begin{tabular}{|c|c|c|c|c|}
\hline \multirow[b]{2}{*}{ Habitat preference } & \multirow[b]{2}{*}{ Species } & \multicolumn{3}{|c|}{ Density of mortalities ha ${ }^{-1}$ (and count) } \\
\hline & & Fire $\mathrm{A}$ & Fire $B$ & Fire $\mathrm{C}$ \\
\hline \multirow[t]{6}{*}{ Strictly fossorial } & Cape centipede-eater (Aparallactus capensis, A. Smith 1849) & $0(0)$ & $0.39(1)$ & $2.5(2)$ \\
\hline & De Coster's garter snake (Elapsoidea sundevallii decosteri, Boulenger 1888) & $0.39(1)$ & $0(0)$ & $1.25(1)$ \\
\hline & Eastern purple-glossed snake (Amblyodipsas m. microphthalma, Bianconi 1850) & $0(0)$ & $0(0)$ & $1.25(1)$ \\
\hline & Maputaland legless skink (Acontias auranticus parietalis, Broadley 1990) & $0.39(1)$ & $0.77(2)$ & $0(0)$ \\
\hline & Jan's shovel-snout (Prosymna janii, Bianconi 1862) & $0.39(1)$ & $0(0)$ & $3.75(3)$ \\
\hline & Zululand dwarf burrowing skink (Scelotes arenicolus, Peters 1854) & $0.39(1)$ & $0(0)$ & $7.5(6)$ \\
\hline \multirow[t]{2}{*}{ Fossorial } & Eastern sand skink (Trachylepis depressa, Peters 1854) & $0.39(1)$ & $1.92(5)$ & $25(20)$ \\
\hline & Wahlberg's snake-eyed skink (Panaspis wahlbergi, A. Smith 1849) & $0(0)$ & $0(0)$ & $2.5(2)$ \\
\hline \multirow[t]{3}{*}{ Surface-living } & Common house snake (Boaedon capensis, Dumeril, Bibron \& Dumeril 1854) & $0(0)$ & $0(0)$ & $1.25(1)$ \\
\hline & Yellow-throated plated lizard (Gerrhosaurus flavigularus, Wiegmann 1828) & $0(0)$ & $0(0)$ & $1.25(1)$ \\
\hline & Short-snouted grass snake (Psammophis brevirostris, Peters 1881) & $0.39(1)$ & $0(0)$ & $0(0)$ \\
\hline \multirow[t]{2}{*}{ Generalist } & Rhombic egg-eater (Dasypeltis scabra, Linnaeus 1758) & $0(0)$ & $0.39(1)$ & $0(0)$ \\
\hline & Southern African python (Python natalensis, A. Smith 1840) & $0(0)$ & $0.39(0)$ & $0(0)$ \\
\hline Arboreal & Cape dwarf gecko (Lygodactylus capensis, Smith 1849) & $0(0)$ & $0(0)$ & $1.25(1)$ \\
\hline \multicolumn{2}{|c|}{ Total density of mortalities ha ${ }^{-1}$ (and count) } & $2.31(6)$ & $4.23(11)$ & $46.25(37)$ \\
\hline \multicolumn{2}{|c|}{ Area of the burn scar (ha) } & 300 & 180 & 300 \\
\hline \multicolumn{2}{|c|}{ Area surveyed within the burn scar (ha) } & 2.6 & 2.6 & 0.8 \\
\hline
\end{tabular}


Table 2 Reptile mortality percentage associated with sites rich in leaf litter and woody cover, and open habitat sites, Tembe Elephant Park, in northern KwaZulu-Natal Province, South Africa, 2015

\begin{tabular}{llrl}
\hline & \multicolumn{3}{l}{ Mortality (\%) } \\
\cline { 2 - 4 } Microhabitat & Fire A & Fire B & Fire C \\
\hline Leaf litter and woody cover & 84.85 & 90.91 & 78.95 \\
Open habitat and grassland & 15.15 & 9.09 & 21.05 \\
\hline
\end{tabular}

(Scelotes arenicolus, Bianconi 1862), and eastern sand skink (Trachylepis depressa, Peters 1854). Carbon particles were observed in the lungs of two eastern sand skinks in addition to pulmonary oedema.

\section{Discussion}

During head fires, energy is vented above ground level (Trollope et al. 2002), with increases in wind speed producing faster moving fire fronts, decreasing the time of direct fire exposure to detritus and fallen woody material that may require prolonged exposure to fire before combustion is initiated (Rein 2013). Wind speed was highest during Fire A, alluding to a faster-moving fire front with lower assumed detritus ignition rates than Fires B and C, which had much lower wind speeds and higher mortality densities. Wind speed during fires thus seems to have an inverse proportional relationship to reptile mortality density, although more quantified replicates would need to be conducted to confirm this.

The spatial orientation within the environment during burning events may predispose or protect reptiles from fire effects. Species-specific habitat utilization may change due to torpor, seasonal migration, mating

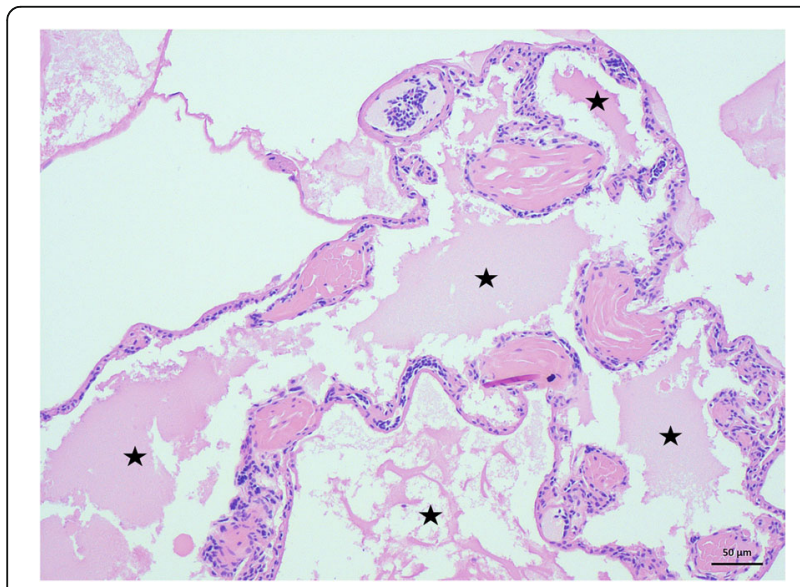

Fig. 1 Pulmonary oedema (stars) observed within lung tissue of a Zululand dwarf burrowing skink (Scelotes arenicolus, Bianconi 1862) from Fire C, Tembe Elephant Park, South Africa, 13 and 14 August and 14 October 2015, during histopathological analyses. Photomicrograph, $100 \times$ magnification, Hematoxylin and Eosin staining. Photographed in situ by Dr. J. Steyl activity, body size, or maturity. Studies documenting the impact of fire on soil vertebrates are scarce (Bigalke and Willan 1982; Neary et al. 1999). Smith et al. (2012) recorded mortalities of leaf-litter reptiles following a wildfire, but none for true burrowing species. Burrowing is considered to offer protection to vertebrates from firerelated hazards (Russell et al. 1999; Engstrom 2010). Burrowing vertebrates are thought to be able to avoid fire-related hazards by digging deeper into the substrate (e.g., Neary et al. 1999). Our results from Tembe Elephant Park, however, indicated that burrowing reptiles were not necessarily protected from fire effects.

Strictly fossorial and fossorial reptiles were well represented within the Tembe Elephant Park samples (Table 1). The shallow burrowing behavior of the eastern sand skink (Branch 1998), seeking shelter from fire instead of fleeing, may result in increased fire mortality, as was recorded during Fire $\mathrm{C}\left(25\right.$ mortalities $\left.\mathrm{ha}^{-1}\right)$. The depth within the soil column at which fossorial reptiles occur may vary according to seasonal reproductive behavior (e.g., Haacke and Bruton 1978; Branch 1998). This may influence the susceptibility of burrowing reptiles to burning as some taxa may prefer shallow soil depths or the surface when seeking mating partners, potentially increasing the exposure of sexually mature adult animals to the effects of fire. Such mating-driven seasonal habitat selection may have resulted in the presence or absence or fluctuating rates of specific soil-adapted species in the observed mortality sample. Alternatively, seasonal use of the surface environment for feeding (e.g., Haacke and Bruton 1978) may predispose certain species to succumb to the effects of fire at specific times of year. Beaupre and Douglas (2012) considered snakes more vulnerable to fires during ecdysis as old, detaching skin impairs their ability to detect and avoid fires. The only snake specimen collected in the process of shedding was the southern African python from Fire B.

Among vertebrates, mortalities caused by fire have been studied extensively in humans, finding mortalities most commonly attributed to toxic gases as part of smoke inhalation. Peracute gas intoxication with carbon monoxide and hydrogen cyanide has been identified as the main mechanisms of death. Heat-induced cardiac arrest through vagal inhibition when hot air or steam is inhaled has also been implicated as an important cause of death during fires (Busuttil 2008; Gill and Martin 2015). The unburned condition of most specimens encountered during surveys prompted suspicion of particulate smoke inhalation as a possible cause of death for Fire $\mathrm{C}$ samples; however, the relative absence of carbon-rich particulate matter and the occasional presence of pulmonary oedema during histopathological examination suggested asphyxiation, heat-induced cardiac arrest, or gas intoxication, such as carbon monoxide and 
hydrogen cyanide poisoning, as the most likely mechanisms resulting in death. Only two eastern sand skinks were considered to have possibly succumbed to particulate smoke inhalation, as carbon particles were present in their airways.

The association of most collected specimens with microhabitats rich in leaf litter follow the fine-scale habitat selection described by Measey (2006) as well as Maritz and Alexander (2008). When considering the histopathological manifestation of detrital combustion on species sheltering in substrate, especially in Fire $\mathrm{C}$, the advective transportation of heated gas products into underlying soil layers as described in Massman et al. (2010) may explain the prevalence of fire-associated mortality to strictly fossorial and fossorial reptiles. It is worth noting that the study site falls within an area that is considered rich in soil-living herpetofauna (Maritz and Alexander 2008) and the implications for these groups of animals may not be relevant for most of southern Africa.

The results from our surveys in Tembe Elephant Park describe potential mechanisms of fire-caused mortality and indicate reciprocity between fire season, environmental conditions, and life history traits in the absence of non-combustible refugia (e.g., rocks). Published observations of fire-induced reptile mortality within multiple types of fire-prone habitats will contribute to improved understanding and therefore predictive power to inform management decisions.

\section{Acknowledgements}

The authors thank Y. Spierenburg, P. Calverley, G. Dene, C. Marchant, J. Preiss, and $\mathrm{E}$. van der Merwe for their assistance in the field, as well as Tembe Elephant Park management for supplying armed field rangers for the fieldwork. Histopathological analyses were conducted at the Pathology Section of the Faculty of Veterinary Science, University of Pretoria. The authors would like to thank the three reviewers of this field note for their comments and suggestions.

\section{Authors' contributions}

PRJ was the lead author, conducted field work, and proposed field work. JCAS conducted histopathological analyses of samples. CCH was the permit administrator and the conservation management liaison, and conducted field work. XC was the academic supervisor of Baccalaureus Technologiae. All authors read and approved the final manuscript.

\section{Funding}

No official funding was provided for this project.

\section{Availability of data and materials}

Histopathological samples are kept in the histopathological sample storage at the Onderstepoort Veterinary Faculty, University of Pretoria, under 3043-16 (Fire A), 3044-16 (Fire B), and 3045-16 (Fire C). Data on species richness and abundance is supplied in the article.

\section{Ethics approval}

Animal ethics approval was granted for the research by the Tshwane University of Technology Animal Research Ethics Committee, reference number AREC2016/05/002. Specimens were collected under Ezemvelo KwaZulu-Natal Wildlife permit number OP 5470/2014.

\section{Competing interests}

The authors declare that they have no competing interests.

\section{Author details}

'Department of Nature Conservation, Tshwane University of Technology, Private Bag X680, Pretoria, South Africa. ${ }^{2}$ Department Paraclinical Sciences, Faculty of Veterinary Science, University of Pretoria, Private Bag X04,

Onderstepoort 0110, South Africa. ${ }^{3}$ Scientific Services, Ezemvelo KZN Wildlife, Tembe Elephant Park, Private Bag X356, KwaNgwanase, KwaZulu-Natal 3973, South Africa.

Received: 28 May 2019 Accepted: 18 December 2019

Published online: 21 January 2020

\section{References}

Bancroft, J.D., and M. Gamble, eds. 2002. Theory and practice of histological techniques. Edinburgh: Churchill Livingstone.

Beaupre, S.J., and L.E. Douglas. 2012. Responses of timber rattlesnakes to fire: lessons from two prescribed burns. In Proceedings of the 4th fire in Eastern oak forests conference, 17-19 May 2011, Springfield, Missouri, USA. USDA Forest Service General Technical Report NRS-P-102, edited by D.C. Dey, M.C. Stambaugh, S.L. Clark, and CJ. Schweitze, pages 192-204. Newtown Square: USDA Forest Service, Northern Research Station.

Bigalke, R.C., and K. Willan. 1982. Effects of fire regime on faunal composition and dynamics. In Ecological effects of fire in South African ecosystems, ed. P. de V. Booysen and N. Tainton, 225-272. Berlin: Springer-Verlag.

Branch, B. 1998. Field guide to snakes and other reptiles of southern Africa. Pretoria: Struik.

Branch, W.B. 2014. Conservation status, diversity, endemism, hotspots and threats. In Atlas and Red List of the reptiles of South Africa, Lesotho and Swaziland. Suricata 1, ed. M.F. Bates, W.R. Branch, A.M. Bauer, M. Burger, J. Marais, G.J. Alexander, and M.S. de Villiers, 22-51. Pretoria: South African National Biodiversity Institute.

Busuttil, A. 2008. Heat-induced injury or death. Chapter 15. In Paediatric forensic medicine and pathology, ed. A. Busuttil and J. Keeling, 317-328. London: CRC Press. https://doi.org/10.1201/b13186.

Dickenson, M.B., J.C. Norris, A.S. Bova, R.L. Kremens, V. Young, and M.J. Lacki. 2010. Effects of wildland fire smoke on a tree-roosting bat: integrating a plume model, field measurements, and mammalian dose-response relationships. Canadian Journal of Forest Research 40: 2187-2203. https://doi.org/10.1139/ X10-148.

Engstrom, R.T. 2010. First-order fire effects on animals: review and recommendations. Fire Ecology 6 (1): 115-131. https://doi.org/10.4996/ fireecology.0601115.

Gill, P., and R.V. Martin. 2015. Smoke inhalation injury. BJA Education 15 (3): 143-148. https://doi.org/10.1093/bjaceaccp/mku017.

Haacke, W.D., and M.N. Bruton. 1978. On two little known snakes from the tropical subtraction zone of South-eastern Africa. Annals of the Transvaal Museum 31 (5): 43-50.

Maritz, B., and G.J. Alexander. 2008. Breaking Ground: quantitative fossorial herpetofaunal ecology in South Africa. African Journal of Herpetology 58 (1): 1-14. https://doi.org/10.1080/21564574.2009.9635575.

Massman, W.J., J.M. Frank, and S.J. Mooney. 2010. Advancing investigation and physical modelling of first-order fire effects on soils. Fire Ecology 6 (1): 36-54. https://doi.org/10.4996/fireecology.0601036.

Masterson, G.P.R., B. Maritz, and G.J. Alexander. 2008. Effect of fire history and vegetation structure on herpetofauna in a South African grassland. Applied Herpetology 5: 129-143. https://doi.org/10.1163/ 157075408784648781.

Matthews, W.S., A.E. Van Wyk, N. Van Rooyen, and G.A. Botha. 2001. Vegetation of the Temebe Elephant Park, Maputaland, South Africa. South African Journal of Botany 67: 573-593. https://doi.org/10.1016/S0254-6299(15)31188-1.

Measey, G.J. 2006. Surveying biodiversity of soil herpetofauna: towards a standard quantitative methodology. European Journal of Soil Biology 42: 103-110. https://doi.org/10.1016/j.ejsobi.2006.07.034

Mucina, L., and M.C. Rutherford, eds. 2006. The vegetation of South Africa, Lesotho and Swaziland. Srelitzia 19. Pretoria: South African National Biodiversity Institute. https://doi.org/10.1016/j.ejsobi.2006.07.034.

Neary, D.G., C.C. Klopatek, L.F. Debano, and P.F. Ffolliott. 1999. Fire effects on belowground sustainability: a review and synthesis. Forest Ecology and Management 122: 51-71. https://doi.org/10.1016/S0378-1127(99)00032-8.

Panzer, R. 2002. Compatibility of prescribed burning with the conservation of insects in small, isolated prairie reserves. Conservation Biology 16 (5): 12961307. https://doi.org/10.1046/j.1523-1739.2002.01077.x. 
Parr, C.L., and S.L. Chown. 2003. Burning issues for conservation: a critique of faunal fire research in southern Africa. Austral Ecology 28: 384-395. https:// doi.org/10.1046/j.1442-9993.2003.01296.x.

Rein, G. 2013. Smouldering fires and natural fuels. Chapter 2. In Fire phenomena in the earth system - an interdisciplinary approach to fire science, ed. C. Belcher, 15-34. Wiley. https://doi.org/10.1002/9781118529539.ch2.

Russell, K.R., D.H. Van Lear, and D.C. Guynn. 1999. Prescribed fire effects on herpetofauna: review and management implications. Wildlife Society Bulletin 27 (2): 374-384.

Smith, A., B. Meulders, C.M. Bull, and D. Driscoll. 2012. Wildfire-induced mortality of Australian reptiles. Herpetology Notes 5: 233-235.

Trollope, W.S.W., L.A. Trollope, and D.C. Hartnett. 2002. Fire behaviour a key factor in the fire ecology of African grasslands and savannas. In: Proceedings of the IV international conference on forest fire research, 2002 wildland fire safety summit, Luso, Coimbra, Portugal, 18-23 November 2002, ed. D.X. Viegas. Rotterdam: Millpress.

\section{Publisher's Note}

Springer Nature remains neutral with regard to jurisdictional claims in published maps and institutional affiliations.

\section{Submit your manuscript to a SpringerOpen ${ }^{\circ}$ journal and benefit from:}

- Convenient online submission

- Rigorous peer review

- Open access: articles freely available online

- High visibility within the field

Retaining the copyright to your article

Submit your next manuscript at $\boldsymbol{\wedge}$ springeropen.com 